\title{
THE GENERIC PATTERNS OF THE MALAY WRITTEN WEDDING INVITATIONS: A PRELIMINARY STUDY
}

\author{
Salihah Abdullah ${ }^{\mathbf{1}}$ \\ Universiti Teknologi MARA (UiTM) Academy of Language Studies, \\ Cawangan Terengganu, Kampus Kuala Terengganu, Malaysia. \\ (Email: salih537@uitm.edu.my) \\ Juliana Mohd Nor ${ }^{2}$ \\ Universiti Teknologi MARA (UiTM) Academy of Language Studies, \\ Cawangan Terengganu, Kampus Kuala Terengganu, Malaysia. \\ (Email: julia073@uitm.edu.my) \\ Nor Jawanees Ahmad Hanafiah ${ }^{3}$ \\ Universiti Teknologi MARA (UiTM) Academy of Language Studies, \\ Cawangan Terengganu, Kampus Kuala Terengganu, Malaysia. \\ (Email: norja293@uitm.edu.my) \\ Norhamimah Rani ${ }^{4}$ \\ Universiti Teknologi MARA (UiTM) Academy of Language Studies, \\ Cawangan Terengganu, Kampus Kuala Terengganu, Malaysia. \\ (Email: norhamimah@uitm.edu.my) \\ Ngo Kea Leng 5 \\ Universiti Teknologi MARA (UiTM) Academy of Language Studies, \\ Cawangan Terengganu. Kampus Kuala Terengganu, Malaysia. \\ (Email: klngo@uitm.edu.my)
}

Received date: 31-07-2019

Revised date: 04-08-2019

Accepted date: 19-09-2019

Published date: 19-09-2019

To cite this document: Abdullah, S., Mohd Nor, J., Hanafiah, N. J. A., Rani, N., \& Ngo, K. L. (2019). The Generic Patterns of The Malay Written Wedding Invitations: A Preliminary Study. International Journal of Humanities, Philosophy and Language, 2(7), 120-128.

DOI: $10.35631 / \mathrm{ijhpl} .270010$

\begin{abstract}
In the Malay culture, a wedding invitation is regarded as one of the most essential parts of the nuptials. It does not only convey good news but also requests the presence of all relatives, friends and social acquaintances to gather at a certain place and time for solemnization and reception ceremonies. A wealth of research on patterns of wedding invitations has been conducted among various societies throughout the world. However, not much genre-analysis research relating to wedding invitations among the Malays can be found. Hence, the present preliminary study was conducted to explore various patterns of Malay written wedding invitations. Adopting the genre analysis model proposed by Swales, 60 samples of the Malay wedding invitation cards were analyzed in terms of move orders, obligatory and optional moves. The cards were randomly selected from a collection of invitations from 2015 to 2019. This study revealed that the Malays frequently employed seven generic moves in their written wedding invitations.
\end{abstract}

Keywords: Wedding Invitations, Move Orders, Swales, Malays 


\section{Introduction}

One of the most significant processes in the preliminary phase of marriage planning is writing the wedding invitation card. It refers to a printed card requesting the relatives, friends, neighbors and acquaintances to attend a wedding ceremony. Salwameh (2015) describes the wedding card as a formal invitation and announcement of the marriage with the purpose of not just informing and inviting but to give details of place and time, to gather information about number of attendees (if with RSVP) as well as to show the wealth and social status of the couple and many other significant. The wedding invitation cards are normally sent to the intended guests about one to three weeks before the date of the wedding. This enables them to make travel plans if they live far away or to take more time off from their jobs and commitments to celebrate the day. If the wedding takes place in a Malay traditional village, all villagers are normally invited. It has become a custom for the parents of the brides/grooms to meet each of the village folk to invite them to the wedding ceremony. This is to avoid any hard feelings among the village folks, who might have been accidentally left out during the distribution of the wedding cards. A wedding invitation card should contain certain essential information which includes the names of the bride and groom, the details of the ceremony which are the location, date and time it will be held. According to Raheja and Puri (1995), the wedding invitation cards typically have several important information: (1) the announcement of the wedding reception; (2) the name(s) of the host; (3) the name of the bride and groom; (4) the date; (5) time; (6) and address of the ceremony.

\section{Objectives of the study}

This study aims to:

1. Identify the generic patterns of the written wedding invitations of the Malaysian Malays.

2. Identify the obligatory and optional moves of the written wedding invitations of the Malaysian Malays.

\section{Research Questions}

1. What are the generic patterns of the Malay written wedding invitations?

2. What are the obligatory and optional moves used in the Malay written wedding invitations?

\section{Problem Statement}

Various research has been conducted on patterns of wedding invitations but there is a significant gap in the research findings involving materials from South East Asia, particularly the Malaysian Malays. The previous research on the Bruneian written wedding invitations, conducted by Clynes and Henry (2004) offers a valuable insight into similarities and differences of the Malay written wedding invitations with those of the Middle East. A study conducted by Siti Rohana and Kuang (2017) had focused mainly on the language and culture aspects presented in the wedding cards of three ethnic groups in Malaysia. The study revealed that the Malays, Chinese and Indians do maintain their unique cultures and beliefs despite the influence of the Western practices in the modern Malaysian wedding cards. This study does not contribute much to the understanding of the Malay written wedding invitation patterns. Due to scarce literature of genre-analysis studies which relate to the Malay written wedding invitations, more studies should be conducted to investigate the subject matter. 


\section{Literature Review}

Since the introduction of Swales' (1990) genre analysis model, many genre-analysis related studies have been carried out to compare written wedding invitation patterns. This genre analysis approach is especially popular among the researchers in the Middle East. Al Ali (2006) studied the wedding invitation patterns and the impacts that the socio-cultural norms and values had on this type of writing in 200 Arabic wedding invitations. He identified eight generic components and concluded that religious attachment and masculine kinship authority influenced the construction and choice of written components, the lexical choices and naming practices. An Iranian study of wedding invitation patterns by Sharif and Yarmohammadi (2013) identified seven generic moves employed by the Iranians when constructing the wording in their wedding invitation cards. Both studies confirm that wedding invitations do have certain generic patterns. The findings of other studies on this genre also discovered that socio-cultural factors as well as time and modern technology influence the moves and the writing of the wedding invitations.

Other Iranian research on wedding invitation patterns by Faramarzi, Elekaie and Tabrizi (2015), Sharif and Yarmohammadi (2013), and Mehdipour, Eslami and Alami (2015) confirmed that Iranian wedding invitations have generic moves which are similar to other wedding invitations in the western culture. However, invitation pattern dissimilarities which are influenced mainly by religious and social cultural factors have also been discovered. Sadri (2014), who studied the Iranian wedding invitations found that the moves are generically similar but over the years, the Iranians tend to favour informality and creativity in writing the wedding invitations. Faramarzi, Elekaie and Tabrizi (2015) concluded that the moves used in the invitations are either obligatory or optional but overall, they are determined by the religious and cultural factors.

Other than the Iranian wedding invitations, other studies are also conducted in Jordan and Egypt. A study on this genre conducted by Sawalmeh (2018) who analysed the writing patterns of the Jordanian wedding invitations found that the Jordanian wedding invitations contain moves which are generally similar to other middle eastern wedding invitations. It also supports the idea that the pattern of moves and choice of words are religiously influenced and masculine in nature. The writing pattern is also influenced by other factors such as language (the use of rhyme, alliteration and metaphors and other literary devices), cost (short sentences to fit into limited space) and norms (preference for adult attendees). In his previous study, Sawalmeh (2014) highlighted the differences and similarities in the structure of the Jordanian Muslim's wedding invitations compared to those of Jordanian Christian's. He revealed that social, cultural and religious factors are significant for both groups of people in writing their wedding invitation cards. Furthermore, Gomaa and Abdel-Malek (2010) study stated that in Egyptian Arab society, religious content is included and taken from the Quran and the Bible depending on the religion of the people who send the invitation. Other than that they also noted that the structure of the wording in the card which is language and culturally influenced such as use of Arabic language which means reading from right to the left and the usage of excessive titles to reflect status in society.

One significant study on the Malay wedding invitation patterns was conducted by Clynes and Henry (2004). They studied the Brunei Malay wedding invitation patterns and focused on the Bruneian students' ability to identify the moves which were visible in the Brunei Malay wedding invitation cards. The Brunei Malay wedding invitations generally use both Arabic and Roman alphabets which are similar to those of the middle eastern, in the sense that they are religiously influenced as they contain Islamic phrases or verses. The wedding invitations 
of the Brunei Malay also clearly differentiate the social status of the persons being invited by their social ranking. It is evident in the social title they hold with their names for example, Pehin/Dato/Datin/Awang/Dayang. In short, although the study was conducted in 2004, it is a good reference for future genre-analysis studies of the Malay wedding invitation card patterns. Since time may have played a factor in influencing current writing pattern of the Malay wedding invitations, it is timely that more research on the patterns of the Malay wedding invitations be conducted as most wedding card invitation studies focus on the western and middle eastern cultures. The lack of information regarding the writing pattern of the Malay wedding invitations limits the knowledge about the values, speech and thinking patterns of the Malay community in Malaysia. Extending this kind of research would give more opportunities and materials for comparison of writing patterns among different sets of cultures and subcultures.

\section{Data and Procedures}

60 samples of the Malay wedding invitation cards were randomly selected from a collection of invitations from years 2015 to 2019. Some of the cards were gathered from the family members and close friends of the researchers. Using Swales' (1990) move structure analysis, the cards were carefully examined to identify the generic patterns of the written wedding invitations of the Malaysian Malays and the move orders, obligatory and optional moves.

\section{Results and Discussions}

\section{The Generic Components and Move Orders of The Malay Wedding Invitation Cards}

The analysis found seven generic move components in the Malay invitation cards.

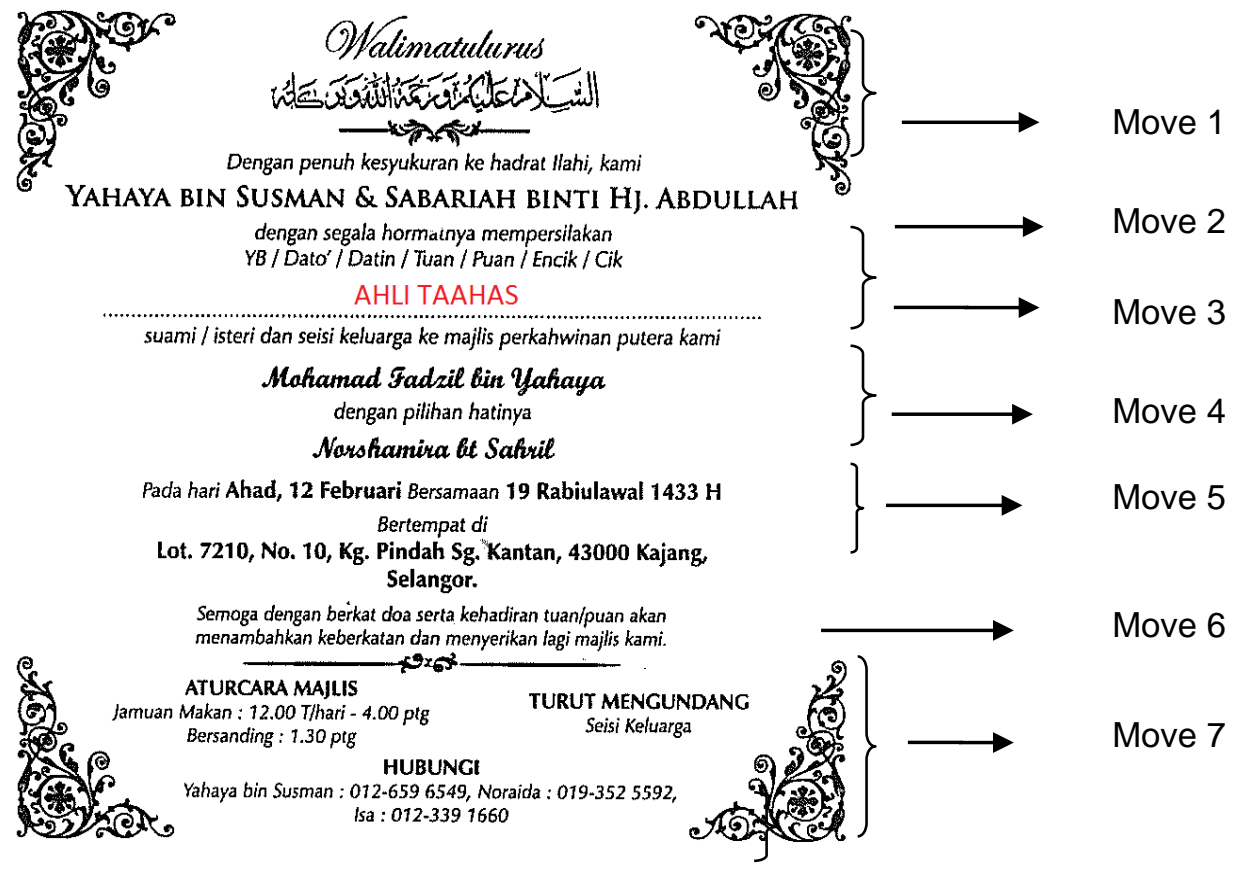

Figure 1: Generic Move Components in a Sample of the Malay Wedding Invitation Card 


\begin{tabular}{|c|c|c|c|c|}
\hline Move & $\begin{array}{c}\text { Move } \\
\text { Component }\end{array}$ & Example Move Presentation & Frequency & $\begin{array}{c}\text { Percentage } \\
(\%)\end{array}$ \\
\hline $\begin{array}{c}\text { Move } \\
1\end{array}$ & Opening & $\begin{array}{l}\text { As-salāmu 'alaykum } \\
\text { Quranic verse(s) } \\
\text { Others }\end{array}$ & $\begin{array}{c}45 \\
4 \\
11\end{array}$ & $\begin{array}{c}75 \\
7 \\
18\end{array}$ \\
\hline $\begin{array}{c}\text { Move } \\
2\end{array}$ & $\begin{array}{l}\text { Identifying the } \\
\text { Inviters }\end{array}$ & $\begin{array}{l}\text { Father's name \& Mother's name } \\
\text { Parents \& their nicknames } \\
\text { Parents \& their titles } \\
\text { Single parent } \\
\text { Elder brother }\end{array}$ & $\begin{array}{c}26 \\
17 \\
10 \\
4 \\
3\end{array}$ & $\begin{array}{l}43 \\
28 \\
17 \\
7 \\
5\end{array}$ \\
\hline $\begin{array}{c}\text { Move } \\
3\end{array}$ & $\begin{array}{l}\text { Inviting the } \\
\text { Guests }\end{array}$ & $\begin{array}{l}\text {... solicit your benign presence and } \\
\text { blessings on the auspicious } \\
\text { occasion of our daughter's } \\
\text { wedding ceremony }\end{array}$ & 60 & 100 \\
\hline $\begin{array}{c}\text { Move } \\
4\end{array}$ & $\begin{array}{l}\text { Identifying the } \\
\text { Bride } \\
\text { and Groom }\end{array}$ & Bride's name and Groom's name & 60 & 100 \\
\hline $\begin{array}{c}\text { Move } \\
5\end{array}$ & $\begin{array}{l}\text { Situating the } \\
\text { ceremony }\end{array}$ & $\begin{array}{l}\text { On ... (Day \& Date of Ceremony- } \\
\text { in Gregorian and Islamic } \\
\text { Calendars } \\
\text { at (address ceremony) }\end{array}$ & 60 & 100 \\
\hline $\begin{array}{c}\text { Move } \\
6\end{array}$ & Closing & $\begin{array}{l}\text { Your presence at this celebration } \\
\text { of love will be greatly appreciated. } \\
\text { Thank you. }\end{array}$ & 34 & 57 \\
\hline $\begin{array}{l}\text { Move } \\
7\end{array}$ & $\begin{array}{l}\text { Notification } \\
\text { (Optional moves) }\end{array}$ & $\begin{array}{l}\text { Location } \\
\text { Wedding reception itinerary } \\
\text { Publishing company } \\
\text { Phone numbers } \\
\text { GPS }\end{array}$ & $\begin{array}{c}60 \\
59 \\
50 \\
60 \\
7\end{array}$ & $\begin{array}{c}100 \\
98 \\
83 \\
100 \\
12\end{array}$ \\
\hline
\end{tabular}

Table 1: The Generic Patterns of the Malay Written Wedding Invitations

\section{Opening}

This introductory move is an obligatory component that exists in the Malay wedding invitation cards. It consists of specific quotation directly taken from the Quran (7\%) like In the Name of Allah and prayers for the brides and grooms. About $75 \%$ of the opening started with $a$ greeting 'As-salämu 'alaykum' which means peace be upon you and $18 \%$ used others such as 'Walimatul Urus' or celebrating the wedding ceremony. Clynes and Henry (2004) and Al-Ali (2006), stated that anything starts with the God's names or words is believed to bring blessings to the newlyweds. It is also a sign of belief and adherence to Islam. Muslims regularly use the greeting every time they meet and communicate with each other in social, religious and other contexts.

\section{Identifying the Inviters}

The second obligatory move is stating the names of people who extend the invitation (43\%). In the Malay culture, the wedding invitations are issued by the parents of the bride or groom as they are the hosts of the wedding ceremony. The father's name will appear first on the card as he is the guardian and the most prominent person in the family. The name of the mother is stated next. If the bride or groom's father has passed away, the mother's name will be used as 
a representative of the family (7\%). If the bride or groom is an orphan, then the brother or the elder siblings will take the responsibility of issuing the cards or act as the inviter(s) (5\%). $28 \%$ of the invitation cards contained the nicknames of the inviters which help the guests to identify the hosts of the ceremony. The title Haji or Hajjah (Haj) which declares that the person has performed the pilgrimage, was found in ten cards (17\%). None of the invitation cards contained the academic and professional titles of the inviters presumably because the cards were collected only among the middle-class society. The researchers believe that such titles may be found in a wider collection of cards which include the upper-class society and that will be the aim of our future research. In contrast, the academic and professional titles such as doctor, engineer and lawyer have high frequency in many Arab countries (Al-Ali, 2006) as the titles mirror the inviters' social status and help them to gain honour and respect from the society.

\section{Inviting the Guests}

The third move, which is inviting the guests appeared in all cards (100\%) as an invitation to the wedding commemoration. It represents the essential part and precisely demonstrates the communicative purpose of the invitation cards. This move allows the inviters, specifically the bride and groom's parents to politely ask for the guests to be present in the wedding ceremony. The analysis of the third move revealed that social ranking of the guests such as YB/Dato'/Datin/Tuan/Puan/Encik/Cik were generally mentioned in the cards. This finding supports Clynes and Henry's (2004) study which differentiates the status of the persons invited by using Pehin/Dato/Datin/Awang/Dayang.

\section{Identifying the Bride and Groom}

This move, identification of the bride and groom appeared in all cards (100\%). This obligatory move identifies who will be married and the full names of the bride and groom will be formally mentioned in the cards. In the Malay culture, their names are written with their respective fathers' names. In some cases, the words bin or binti are also used to indicate that one is a son or daughter of the father. Some phrases used to invite the guests include menjemput ke Majlis Perkahwinan Puteri kami / mengundang ke Majlis Kesyukuran Putera kami, followed by the bride and groom's names. In a typical Malay wedding, the bride and groom will issue their invitation cards separately, as they will have two separate receptions; one will be at the bride's house and another one is at the groom's. The bride's family will hold a wedding ceremony, and after a few days, the groom's family will host a similar ceremony called the 'majlis menyambut menantu' or a traditional Malay ceremony to welcome the daughter-in-law. By having two separate receptions, the bride and groom can personally meet their relatives, friends and neighbours. It also offers a possibility for the invitees to decide which of the two receptions to attend according to their convenience and availability.

\section{Situating the Wedding Ceremony}

This move, situating the wedding ceremony is important as it states the information about time, date and location of the wedding celebration. This obligatory move appeared in $100 \%$ of the invitation cards. The information facilitates friends, relatives and well-wishers of the bride and groom's families to participate in the occasion.

\section{Closing}

The finding revealed that $57 \%$ of the invitation cards included the move, which is closing. It is considered obligatory in the Malay wedding invitations. It consists of earnest phrases in which the inviters express their gratitude to the invitees who attend and share the joy of the 
occasion. Sometimes, in this closing section, the inviters also seek the invitees to pray for the blessings from Allah so that the bride and groom will be bestowed with happiness and love in their marriage.

\section{Notification}

The last move, which is notification displays extra information regarding the wedding ceremony. It was found that all the invitation cards included some notifications such as a graphic illustration of the wedding location (100\%) to help the guests find the direction to the bride or groom's house. The illustration is normally simple, concise and accurate with landmarks of the town, village or place which could lead them to the exact location of the ceremony. Only 7 cards (12\%) provided the GPS coordinates which shows the best route to the location of the ceremony. This is to avoid the guests wasting their time navigating in an unfamiliar area. Stating the phone numbers of the host family has become a trend as it enables the guests to contact them easily. This feature was noticeable in all cards (100\%). The next notification was the tentative of the reception. It provides precise information of the wedding reception program. $98 \%$ of the cards included the details of time when the ceremony began and ended. Lastly, $83 \%$ of the cards included the name of the publishing company which is actually part of the company's strategy to promote the company's products.

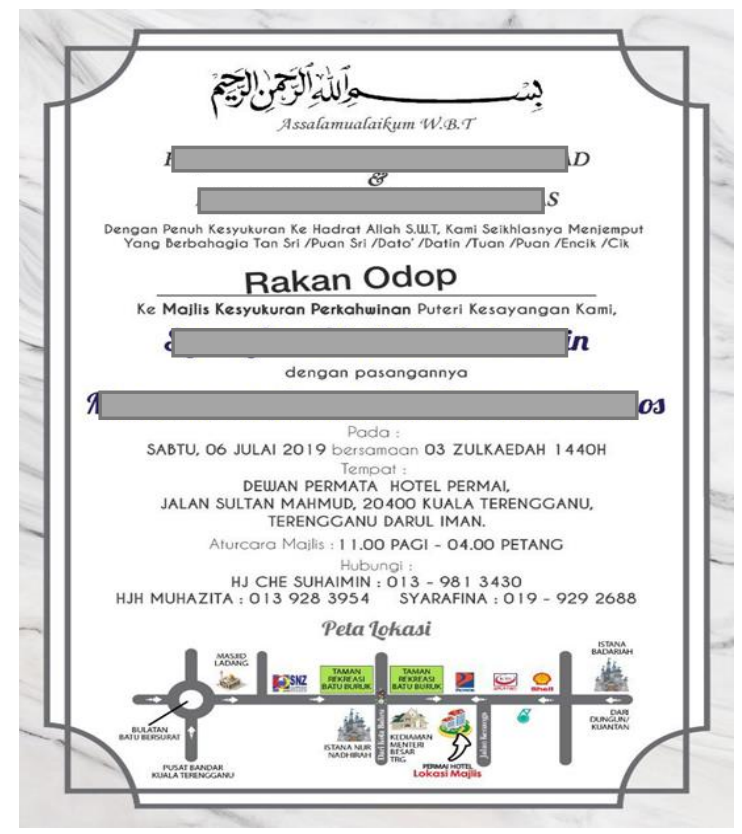

\section{Figure 2: A Sample of the Malay Wedding Invitation Card with a Graphic Illustration of the Wedding Location}

\section{Conclusion}

This study identified seven generic component moves namely: (1) opening, (2) identifying the inviter, (3) inviting the guests, (4) identifying the bride and groom, (5) situating the ceremony, (6) closing and (7) notification. The linguistic components involve the wording of the invitation which provides the details of the ceremony. The Malay wedding invitations begin with Quranic verses, prayers, and beautiful words, phrases, and clauses which are similar to the findings from the Arabic setting. In short, despite having differences, the Malaysian Malay written wedding invitations share some similarities with other wedding invitations from other cultures in the west, the Middle East and Brunei. In general, the invitations employ similar moves. However, due to religious and cultural diversities, the 
invitations of the Malays are evidently different from other countries. Al Momani and Alrefae (2010) claimed that in Jordanian wedding invitations, prototypical features of Jordanian culture are apparent. Thus, there is a big possibility that wedding card invitation may differ from culture to culture. Apparently, the Malays in general include Islamic phrases in their wedding invitations. They also value culture as the input of cultural norms which is apparent in the moves especially when addressing the social ranking of the invitees. The inclusion of content like location graphic illustration and GPS coordinates is clearly an evidence of how modern technology has significantly influenced the content of the wedding invitations. Such inclusion is common in modern society as couples tend to include different discursive discourse practices that caters to their own interests which is influenced by current trends or purposes (Mirzaei \& Eslami 2013) In conclusion, more studies should be done to delve into this genre as the findings would generate interesting insights of the topic. Future studies may investigate the influence of technology and the impacts it has on the traditional written wedding invitations.

\section{References}

Al-Ali, M. N. (2006). Religious affiliations and masculine power in Jordanian wedding invitation genre. Discourse \& Society, 17, 691-714. http://dx.doi.org/10.1177/0957926506068428

Al Momani, K. R., \& Alrefae, D. F. (2010). A Socio-Textual Analysis of Written Wedding Invitation in Jordanian Society. LSP Journal-Language for special purposes, professional communication, knowledge management and cognition, 1(1).

Clynes, A. \& Henry, A. (2004). Introducing genre analysis using Brunei Malay wedding invitations. Language Awareness, 13, 225-242. http://dx.doi.org/10.1080/09658410408668809

Faramarzi, S., Elekaei, A., \& Tabrizi, H. H. (2015). Genre-based discourse analysis of wedding invitation cards in Iran. Journal of Language Teaching and Research, Vol. 6, No. 3, pp. 662-668, DOI: http://dx.doi.org/10.17507/jltr.0603.25

Gomaa, Y. A., \& Abdel-Malak, A. G. (2010). Genre Analysis of Egyptian Arabic Written Wedding Invitation. Journal of the Faculty of Arts, 26, 75-101.

Mehdipour, S., Eslami, Z. R. \& Allami, H. (2015). A comparative sociopragmatic analysis of wedding invitations in American and Iranian societies and teaching implications. Applied Research on English Language, 4 (2), 62-77.

Mirzaei, A., \& Eslami, Z. R. (2013). Exploring the variability dynamics of wedding invitation discourse in Iran. Journal of Pragmatics, 55, 103-118.

Raheja, N. \& Puri, A. (1995). How to arrange a wedding? University of Virginia. UBS Publishers and Distributors.

Siti Rohana Mohd Thani, \& Kuang, C. H. (2017). Vitality of language and culture in Malaysian wedding cards: A multi-ethnic perspective. Malaysian Journal of Languages and Linguistics (MJLL, 6(2), 48-66. DOI: 10.24200/mjll. vol6iss2pp48-66.

Sadri, E. (2014). Iranian wedding invitations in the shifting sands of time. RALs, 5(1), 91108.

Sawalmeh, M. H. M. (2014). A Sociolinguistic study of Muslim and Christian wedding invitation genre in the Jordanian society. Journal of Advances in Linguistics, 5(1), 448-462.

Sawalmeh, M. (2015). Ceremonial Arabic Writing: A Genre-Based Investigation of Wedding Invitation Cards and Obituary Announcements in Jordanian Society (Doctoral dissertation, University of Huddersfield). 
Sawalmeh, M.H.M. (2018). Jordanian wedding invitation as a genre: An analysis of rhetorical structure and linguistic features. International Journal of Linguistics, Literature and Translation, 1(1), 106-114.

Sharif, M., \& Yarmohammadi, L. (2013). On the Persian wedding invitation genre. SAGE Open, 3(3), 1-9.

Swales, J. (1990). Genre Analysis: English in academic and research setting. Cambridge: Cambridge University Press. 